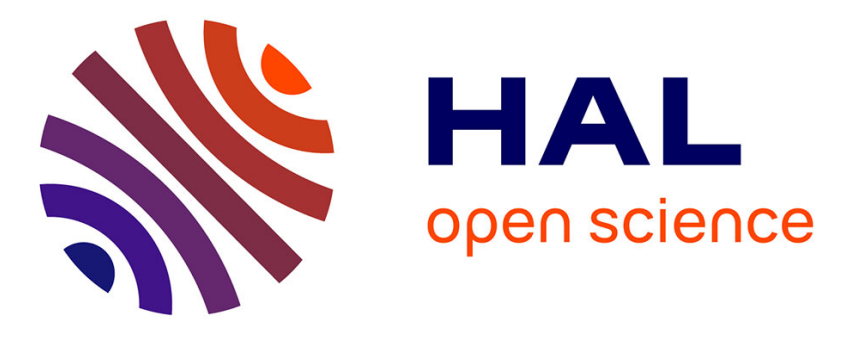

\title{
Mitochondrial structure of Eastern honeybee populations from Syria, Lebanon and Iraq
}

Mohamed Alburaki, Sibyle Moulin, Hélène Legout, Ali Alburaki, Lionel

Garnery

\section{- To cite this version:}

Mohamed Alburaki, Sibyle Moulin, Hélène Legout, Ali Alburaki, Lionel Garnery. Mitochondrial structure of Eastern honeybee populations from Syria, Lebanon and Iraq. Apidologie, 2011, 42 (5), pp.628-641. 10.1007/s13592-011-0062-4 . hal-01003598

\section{HAL Id: hal-01003598 \\ https://hal.science/hal-01003598}

Submitted on 1 Jan 2011

HAL is a multi-disciplinary open access archive for the deposit and dissemination of scientific research documents, whether they are published or not. The documents may come from teaching and research institutions in France or abroad, or from public or private research centers.
L'archive ouverte pluridisciplinaire HAL, est destinée au dépôt et à la diffusion de documents scientifiques de niveau recherche, publiés ou non, émanant des établissements d'enseignement et de recherche français ou étrangers, des laboratoires publics ou privés. 


\title{
Mitochondrial structure of Eastern honeybee populations from Syria, Lebanon and Iraq
}

\author{
Mohamed Alburaki ${ }^{1,4}$, Sibyle Moulin ${ }^{1}$, Hélène Legout $^{1}$, Ali Alburaki $^{2}$, \\ Lionel GARNERY ${ }^{1,3}$

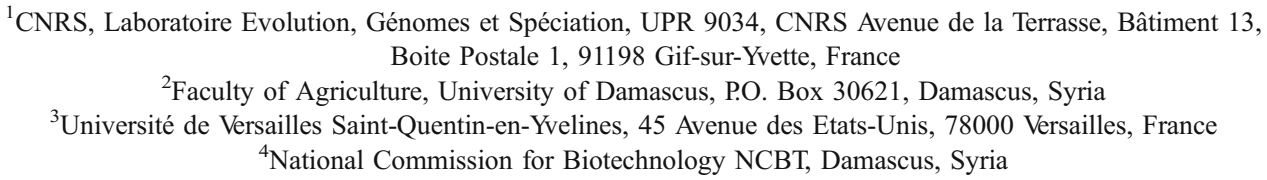

Received 8 November 2010 - Revised 21 January 2011 - Accepted 22 January 2011

\begin{abstract}
Honeybees (Apis mellifera) from Syria $(n=1,624)$, Lebanon $(n=177)$, and Iraq $(n=35)$ were collected for genetic analysis. These samples were analyzed by the cleaved amplified polymorphisms technique using mitochondrial DNA (mtDNA) as a molecular marker in their COI-COII intergenic region (Cytochrome Oxidase I and II). Polymerase chain reaction amplicons (500-950 bp) were subjected to restriction analysis by DraI enzyme. The restriction profiles were analyzed and compared with the existing mtDNA markers on polyacrylamide gels. Sixteen new haplotypes were identified, 14 of them on the African lineage A, one new haplotype on the North Mediterranean lineage $\mathrm{C}$ and one other on the West Mediterranean lineage M. DNA sequences of all these haplotypes were subsequently determined. We also identified five other haplotypes that had been described in a previous study. These five haplotypes were renamed and grouped more appropriately with the subgroup Z, rather than with the Oriental lineage O. The sequence structures of these novel haplotypes clearly display the specific characteristics of the African branch (A). However, they differ from the African haplotypes by a new restriction site; therefore, they have been moved into a new subgroup. We conclude that $A$. mellifera syriaca subspecies does not belong to the Oriental lineage $\mathrm{O}$, but is situated geographically in an area of contact between the $\mathrm{A}$ and $\mathrm{O}$ lineages.
\end{abstract}

Apis mellifera syriaca / CAPS / haplotype / honeybee / intergenic region COI-COII / Cyt b / mtDNA

\section{INTRODUCTION}

Based on morphometrical approaches, the honeybee (Apis mellifera L.) has been subdivided into four different lineages: (1) the West Mediterranean lineage $(\mathrm{M})$, which includes the Western European subspecies A. mellifera mellifera; (2) the North Mediterranean lineage (C); (3) the African lineage (A), which groups the

Corresponding author: M. Alburaki, alburaki@legs.cnrs-gif.fr Manuscript editor: David Tarpy
African honeybee subspecies; and (4) the Oriental lineage $(\mathrm{O})$, which is distributed in the Middle East and represented mainly by Caucasian and Turkish honeybees A. mellifera caucasica and A. mellifera anatoliaca, respectively (Ruttner 1988). The Syrian honeybee subspecies (A. mellifera syriaca), present in the valleys east of the Mediterranean (Syria, Lebanon, and Jordan), was described by Bodenheimer (1941). It is the smallest of all Oriental and European races of A. mellifera; only African races, including yemenitica, are smaller (Ruttner 1988). The Syrian honeybee subspecies, and its relationship to the lineages 
described above, is of interest for a number of reasons. First, it is evident from the distribution map of honeybee races of the Near East published by Ruttner (1988) that honeybees in parts of Syria, Jordan, and Iraq have not yet been studied. It is therefore unknown whether the Syrian bee, reported in Lebanon and the far west of Syria and Jordan, also occur east of these areas. Second, the fairly compact $A$. mellifera syriaca cluster is positioned peripheral to the oriental lineage and very close to the African races in all of the multivariate analyses presented by Ruttner (1988). Third, in the 3-D phenogram of $A$. mellifera that characterizes the four evolutionary lineages (Ruttner 1988), the Syrian honeybee clearly appears in the A branch next to $A$. mellifera meda. According to Ruttner's classification, the honeybee subspecies A. mellifera anatoliaca, which is naturally distributed over most of the Turkish territory, belongs to the $\mathrm{O}$ branch. This Turkish bee comes into contact with the meda bee in southeastern Turkey, but we do not know the exact limits of this contact with the Syrian honeybee in the north of Syria. Molecular genetic techniques, including analysis of mitochondrial DNA (mtDNA) and microsatellite markers, allow reliable classification of honeybee subspecies (Smith et al. 1991; Estoup et al. 1995). Mitochondrial DNA is widely used as a molecular marker to study genetic diversity among populations (Hall and Smith 1991; Franck et al. 2000; Abrahamovich et al. 2007; El-Niweiri and Moritz 2008; Özdil et al. 2009); it is more suitable than the morphometrical approach, which can be affected by environmental factors (Avise et al. 1987). Hence, the first three lineages (A, C, and M) were later confirmed using molecular techniques that involved mtDNA (Garnery et al. 1991, 1995; Smith et al. 1991) and microsatellite markers (Estoup et al. 1993, 1995). Based upon 75 Lebanese honeybee samples and only a few Syrian samples, Franck et al. (2000) suggested that these populations could belong to the fourth lineage $(\mathrm{O})$, as the mtDNA sequence structures of these samples differed sufficiently from the three other described lineages (A, C, and $\mathrm{M}$ ). On the other hand, Kandemir et al. (2006) expressed concern that designating this distinct mitochondrial lineage as "O" may cause confusion with the $\mathrm{O}$ morphological lineage described by Ruttner (1988). However, using a large number of single-nucleotide polymorphism markers, Whitfield et al. (2006) sorted the four honeybee evolutionary lineages and, based on nine Syrian honeybee samples, placed Syrian bees in the Oriental branch $\mathrm{O}$ along with the anatoliaca, pomonella, and caucasica subspecies. Given these contradictory views, it appears that sampling honeybees from Syria could provide useful insight into the diversity of the $\mathrm{O}$ lineage of $A$. mellifera. The different opinions on Syrian honeybee classification that have arisen from previous studies might have been inevitable because subspecies located in geographical contact zones or in zones of secondary contact between lineages are not easy to identify. An in-depth analysis of Syrian honeybee populations was necessary for all of these reasons and also to allow us to delimit the contact zones between lineages and to understand the mitochondrial structure of honeybee populations in Syria. Based on an mtDNA marker, we analyzed a large number of populations from three different countries (Syria, Lebanon, and Iraq) and have generated a thorough description of Syrian honeybee genetic diversity and distribution.

\section{MATERIALS AND METHODS}

\subsection{Sampling and DNA extraction}

Honeybee workers $(N=1,836)$ were collected from managed colonies in 2007 and 2008. Samples were collected from 12 Syrian regions, four Lebanese regions, and one Iraqi region. One worker was collected from each colony and 1,634 colonies were sampled in Syria, 167 colonies were sampled in Lebanon, and 35 colonies were sampled in Iraq. The 
location of each of these sampling regions, as well as the number of samples taken in each region, is shown in Figure 1.

Each worker bee was individually preserved in absolute ethanol, and wings were removed and preserved in ethanol for further morphometrical analysis. DNA was extracted from the thorax using the Chelex method (Walsh et al. 1991). Briefly, the thoraxes were ground and added to $0.1-\mathrm{M}$ Tris- $\mathrm{HCl}$ ( $\mathrm{pH} 8.0), 10 \mathrm{mM}$ ethylenediaminetetraacetic acid, $100 \mathrm{mM} \mathrm{NaCl}, 0.1 \%$ sodium dodecyl sulfate, $50 \mathrm{mM}$ dithiothreitol and $0.25 \mathrm{mg} / \mathrm{mL}$ proteinase $\mathrm{K}$. The extractions were placed at $50^{\circ} \mathrm{C}$ for $1 \mathrm{~h}$ followed by $30 \mathrm{~min}$ at $95^{\circ} \mathrm{C}$, to eliminate the enzyme. DNA extractions were centrifuged for $15 \mathrm{~min}$ at $12,000 \mathrm{rpm}$ and were preserved at $-20^{\circ} \mathrm{C}$.

\subsection{PCR amplification and gel electrophoresis}

Standard methods for polymerase chain reaction (PCR) amplification in honeybees were used. PCR amplification of the COI-COII intergenic region of the mtDNAwas performed using PCR primers E2: 5'GGCAGAATAAGTGCATTG-3' and H2: 5'-CAATATCATTGATGACC-3' (Garnery et al. 1993). PCR was carried out in a total volume of $25 \mu \mathrm{L}$, containing
$2.5 \mu \mathrm{L}$ of Taq $5 \times$ buffer (Promega), $1.5 \mathrm{mM} \mathrm{MgCl}_{2}$, 25 pmol of primers E2 and H2 (Garnery et al. 1992), $25 \mathrm{nmol}$ of each dNTP, 0.6 unit of Promega Taq polymerase, and $1.0 \mu \mathrm{L}$ of DNA extract. Each PCR reaction was subjected to an initial denaturation cycle at $92^{\circ} \mathrm{C}$ for $3 \mathrm{~min}$, followed by 30 cyclic reactions. Each of these cycles consisted of three steps: (1) denaturation of the DNA for $30 \mathrm{~s}$ at $92^{\circ} \mathrm{C}$, (2) hybridization of the primers to the template DNA for $1 \mathrm{~min}$ and $30 \mathrm{~s}$ at $47^{\circ} \mathrm{C}$, and (3) elongation of the primer template hybrid for $2 \mathrm{~min}$ at $63^{\circ} \mathrm{C}$. Finally, the mixture was kept at $63^{\circ} \mathrm{C}$ for $10 \mathrm{~min}$ and PCR products were stored at $-20^{\circ} \mathrm{C}$. PCR results were resolved using $1.4 \%$ agarose gel electrophoresis with the molecular marker MIII. PCR products were photographed under UV light after immersion in ethidium bromide. This migration according to the molecular weight of the molecular marker MIII (Roche Diagnostics $\mathrm{GmbH}$ ) enabled us to distinguish the organization of the intergenic region COI-COII.

\subsection{CAPS technique}

Evolutionary lineage and the haplotypic polymorphisms were characterized using the cleaved amplified polymorphisms technique. Briefly, PCR

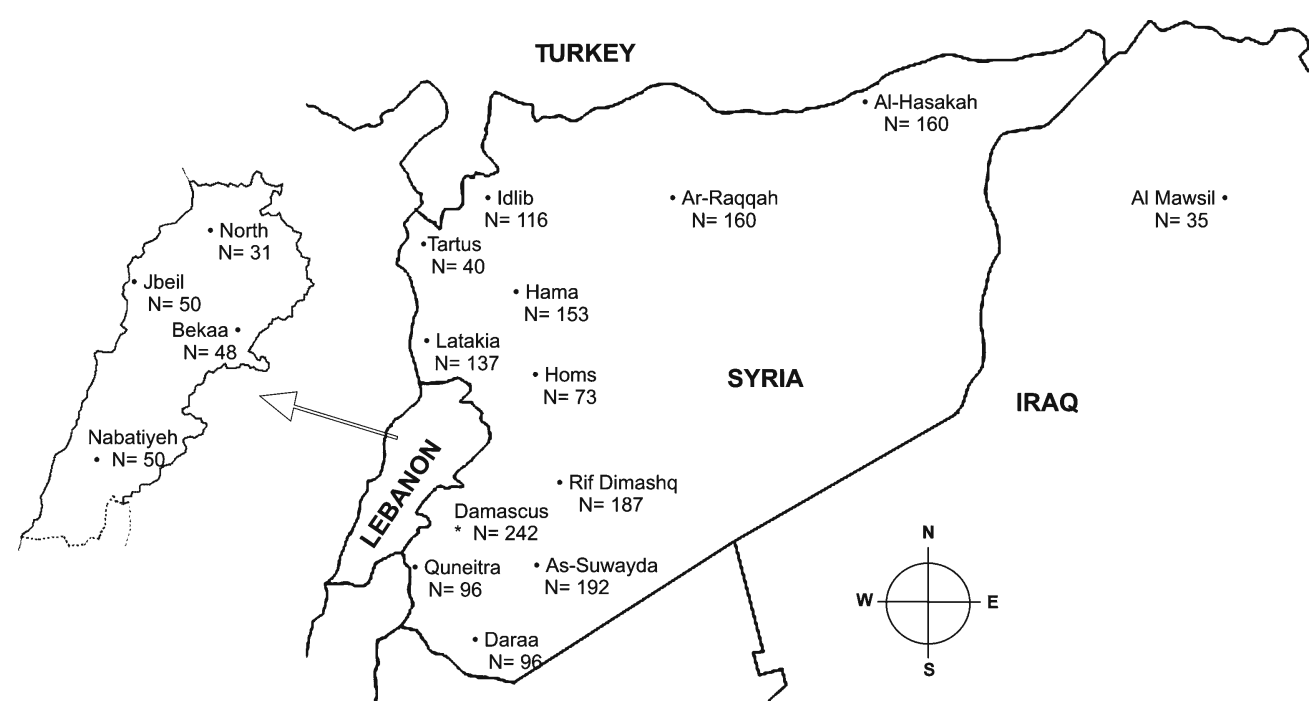

Figure 1. Locations of the sampled regions in Syria, Lebanon, and Iraq. They comprise 12 populations from Syria, one from Iraq, and four from Lebanon. $N$ is the number of honeybees sampled in each population. 
amplicons were cleaved by the restriction enzyme $\mathrm{DraI}$ and were incubated $48 \mathrm{~h}$ at $37^{\circ} \mathrm{C}$. The restricted DNA was loaded on a $7.5 \%$ polyacrylamide gel and run at $150 \mathrm{~V}$ for $3 \mathrm{~h}$. The differentiation in the various sizes of the DNA fragments allows the identification of three mitochondrial lineages and also reveals intralineage polymorphisms (Garnery et al. 1993; Moritz et al. 1994; Sheppard et al. 1999). Unbiased estimates of haplotype diversity (Nei and Tajima 1981) and the corrected haplotype diversity (Garnery et al. 1998) were calculated based on the total number of haplotypes in each population. Estimated values of introgression for each population were also calculated. The correlation coefficient of the north-south gradient for the $\mathrm{A}$ and $\mathrm{C}$ lineages was calculated after omitting the imported haplotypes in each of the populations.

\subsection{Sequence of mtDNA haplotypes}

To interpret and confirm the observed polymorphism using the results of PCR restriction fragment polymorphisms obtained in the COI-COII intergenic region, at least one sample from each newly obtained restriction pattern was sequenced. This step allowed an exact estimate of the size of DraI restriction fragments by eliminating probable mismatch artifacts between the observed restriction fragment pattern and the haplotype reference. It also allowed us to detect small insertions or deletions and substitutions. Sequencing was performed by standard PCR using E2, H2 primers, followed by PCR sequencing with Big Dye Mix and both E2 and $\mathrm{H} 2$ primers. Analysis was done using a four-capillary ABI genetic analyser 3130 . Restriction maps and other alignments were performed using BioEDIT and SEcentral software. Sequences for new haplotypes were submitted to GenBank. In addition to the COI-COII haplotypes sequences, the Cytochrome $b$ (Cyt b) gene of two haplotypes of the $\mathrm{C}$ lineage and six other $\mathrm{Z}$ haplotypes belonging to the $\mathrm{A}$ lineage have been sequenced. Based on these sequences and other reference sequences from GenBank (Pinto et al. 2003), a neighbor-joining tree has been performed on nucleotide distances computed by Kimura's (1980) formula through PAUP* program, version Beta 4.0 (Swofford 2002).

\section{RESULTS}

\subsection{Structure of the $\mathrm{COI}-\mathrm{COII}$ intergenic region}

For all studied samples, the migration profiles of the amplified fragments obtained on agarose $1.4 \%$ gel exhibit four different types of fragments. These four types of fragments correspond to the structures: $\mathrm{Q}, \mathrm{P} / \mathrm{PoQ}, \mathrm{P} /$ PoQQ, and P/PoQQQ (Figure 2).

Five different COI-COII intergenic region lengths were observed within the Syrian honeybee populations and the vast majority were the PoQ length (524 Q, 895 PoQ, 16 PQQ, 178 PoQQ, and 25 PoQQQ). Four different lengths were observed for the Lebanese populations, most of which were also PoQ (20 Q, 112 PoQ, 31 PoQQ, and 4 PoQQQ), while Q length was observed for all Iraqi bee samples (35 Q), Table I.

\subsection{Novel haplotypes identified}

DraI restriction analysis performed on all samples revealed 27 different haplotypes. Among these haplotypes, 22 belonged to the African lineage A, four to the North Mediterranean lineage $\mathrm{C}$, and another one (M63) to the West Mediterranean lineage M. A detailed description of the 17 studied populations is shown in Table I.

Of the 22 haplotypes belonging to the A lineage, 14 haplotypes are new and have not been described in previous studies. Five other haplotypes detected in our samples have been previously described but were classified as belonging to the Oriental lineage, $\mathrm{O}$ (Franck et al. 2001). The three remaining haplotypes (A1, A2, and A3) are classical mitotypes of the African lineage A. The North Mediterranean lineage $\mathrm{C}$ was found in almost all of the populations. Among the classical haplotypes of the $\mathrm{C}$ branch $(\mathrm{C} 1, \mathrm{C} 2$, and $\mathrm{C} 3)$ found in our samples, one new restriction haplotype pattern belonging to this branch was found in the Hama honeybee population, and was named $\mathrm{C} 8$. The numbering of new haplotypes found in our 

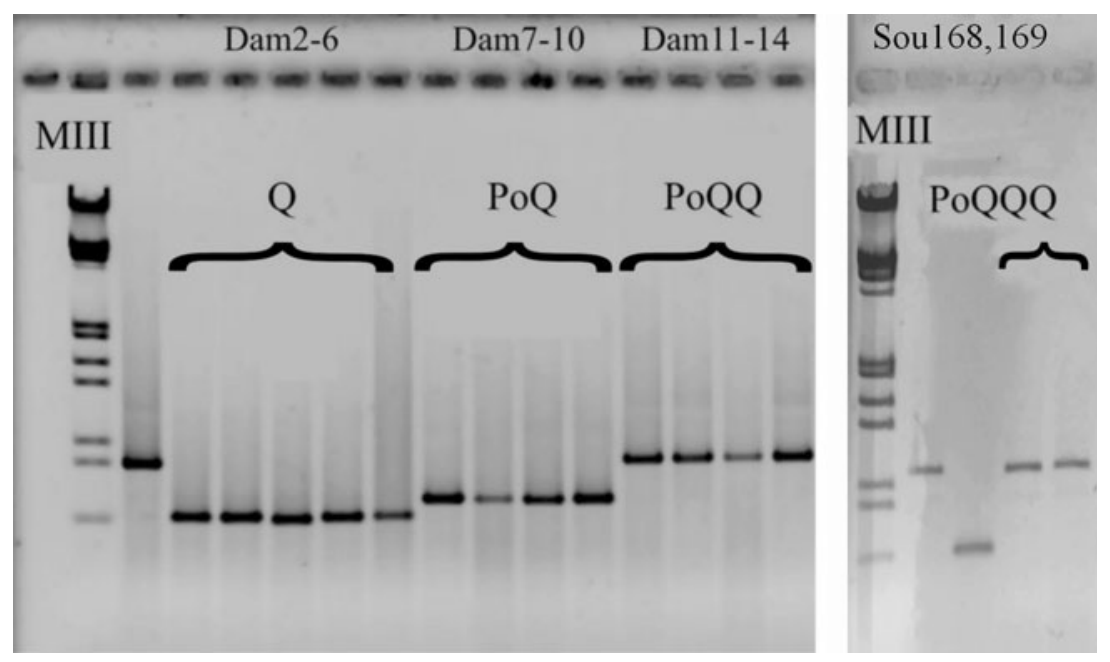

Figure 2. Structural organization of the COI-COII intergenic region of mtDNA migrated on $1.4 \%$ agarose gel. $M I I I$ is a molecular-size marker, $Q$ is the specific sequence of the C lineage, while PoQ, PoQQ, and PoQQQ correspond to the African lineage A.

study was based on the number of the last haplotype found in each evolutionary lineage, according to the established rules for defining a new haplotype in the COI-COII marker (Garnery et al. 1992, 1993). The percentage presence of each evolutionary lineage found in each population is presented in Figure 3. We found that $\mathrm{C}$ lineage frequencies ranged from $100 \%$ of honeybees belonging to this branch in Al-Mawsil (Iraq) to only $6 \%$ in both the Daraa (Syria) and Nabatiyeh (Lebanon) populations (Figure 3). On the other hand, the African lineage A was the most observed lineage in all samples, ranging from 94\% presence in both the Daraa and Nabatiyeh populations down to $9 \%$ in the AlHassaka population. The A lineage was not found at all in the Al-Mawsil population. The calculated correlation coefficient of the northsouth gradient for the $\mathrm{A}$ and $\mathrm{C}$ lineages was highly significant $(R=0.778, P<0.001$, Figure 7$)$. The $\mathrm{M}$ mtDNA lineage was only recorded in low amounts in two Syrian populations: Damascus and Rif Damashq (1\% and 7\%, respectively; Figure 3). This was a single, restricted, and previously unknown haplotype pattern, which we named M63 (Table I). Table II presents haplotype diversity for each population, reflect- ing the level of population diversity. The lowest diversity was observed in Al-Mawsil (Iraq, 0.057 ) and the highest value in Rif Dimashq (Syria, 0.878). However, the presence of imported or non-local haplotypes in each population can bias diversity values. Therefore, corrected haplotype diversity values were calculated by removing the five known imported haplotypes ( $1, \mathrm{C} 3, \mathrm{~A} 2, \mathrm{~A} 3$, and M63) from the calculation (Table II). Surprisingly, corrected haplotype diversity was very low in some populations.

\subsection{COI-COII mtDNA sequencing}

At least one sample of each new haplotype belonging to the African lineage Awas sequenced for the intergenic region COI-COII. The C8 and M63 haplotypes belonging to the $\mathrm{C}$ and $\mathrm{M}$ branches, respectively, were also sequenced. The sequences are available in NCBI GenBank under the following access numbers: M63, HM236202; C8, HM236203; Z1, HM236204; Z1', HM236205; Z2, HM236206; Z3, HM236207; Z4, HM236208; Z7, HM236209; Z8, HM236210; Z9, HM236211; Z12, HM236212; Z13, HM236213; Z15, HM236214; Z16, 


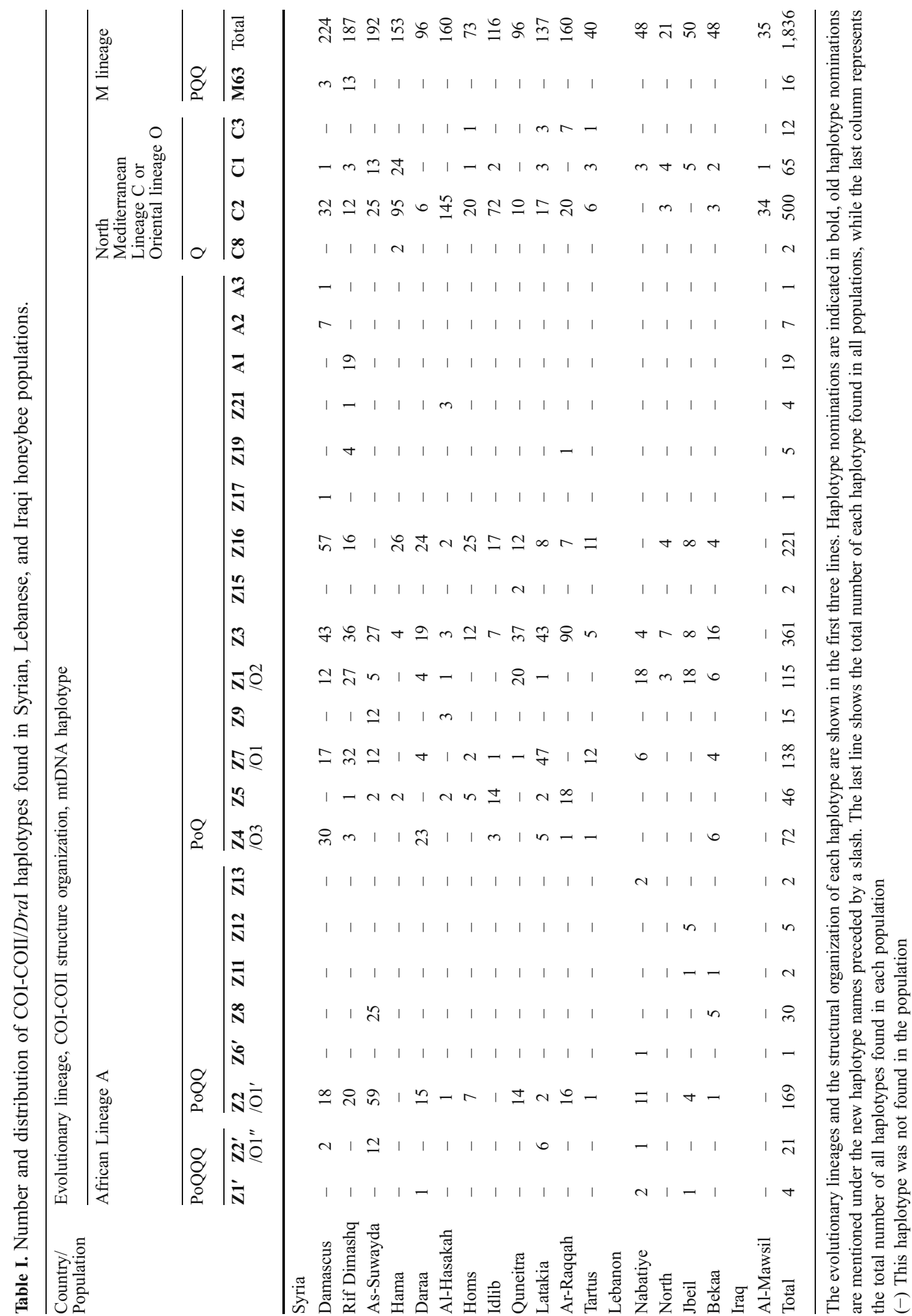




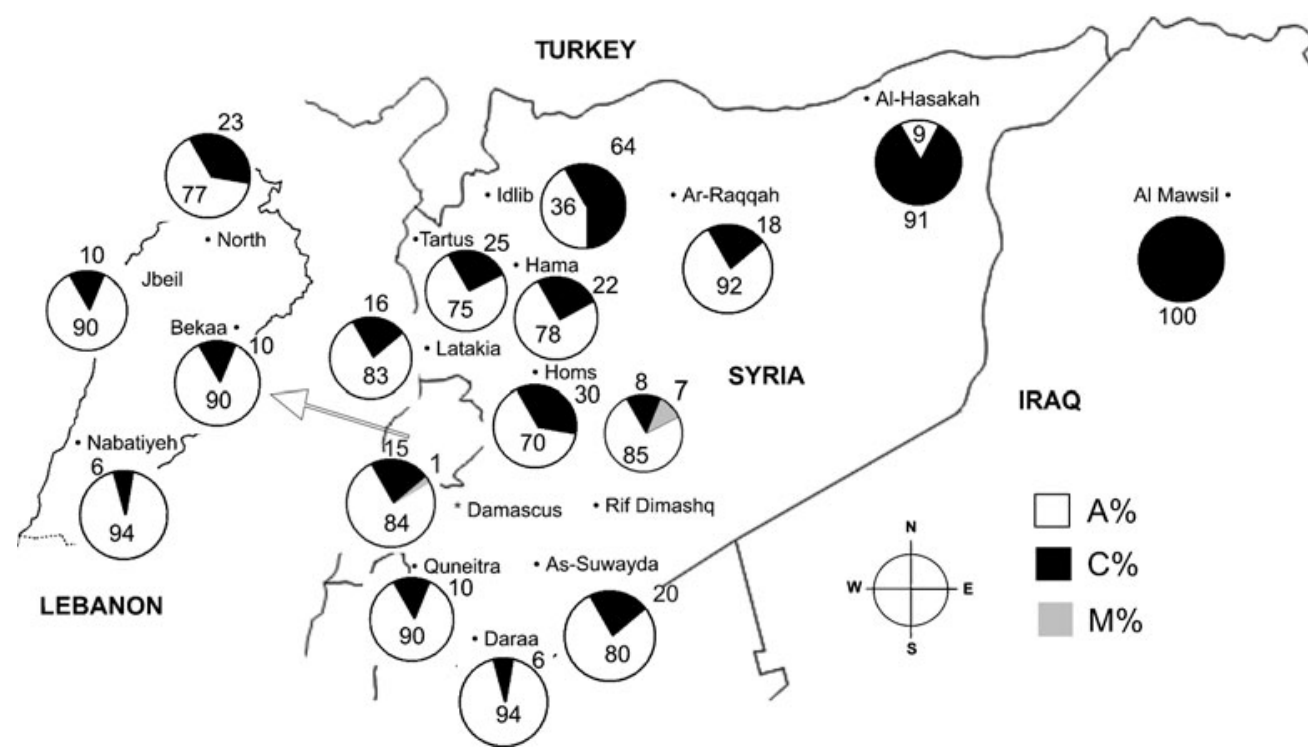

Figure 3. Pie charts of the percentage of the three mtDNA lineages $A, C$, and $M$ in the different Syrian, Lebanese, and Iraqi populations.

HM236215; Z17, HM236216; Z19, HM236217; Z21, HM236218; Z6', HM236219.

Restriction maps for each new haplotype are shown in Figure 4. Based on the sequence results, the length of the COI-COII region for each haplotype found in our study $(\mathrm{Q}, \mathrm{PoQ}, \mathrm{PQQ}$, PoQQ, and PoQQQ) have been determined, along with the restricted DraI sites. All haplotypes belonging to the African lineage A contain the fragment Po in their sequence. This is not the case for the M63 haplotype of the West Mediterranean lineage $M$, in which $P$ is replaced by a $P$ fragment (Figure 4). The sequence of the unique new haplotype found in the North Mediterranean branch (C8) is presented in this paper as an example (Figure 5). The new restriction pattern of the C8 haplotype is due to a deletion of 10 nucleotides in the $\mathrm{Q}$ sequence. Sequencing of this haplotype showed a substitution in the Q fragment at the 203 bp position (Figure 5).

\subsection{Z haplotype subgroup}

The result of neighbor-joining tree analysis is shown in (Figure 6). The topology of this tree discriminates clearly a subgroup of haplotype Z, since all $\mathrm{Z}$ haplotype samples formed an independent subgroup $\mathrm{Z}$ of the African lineage A.

\section{DISCUSSION}

Numerous morphometrical studies have attempted to classify the A. mellifera subspecies. These studies have mainly led to the identification of four different lineages $\mathrm{A}, \mathrm{M}$, C, and O (Ruttner et al. 1978; Ruttner 1988). In one of these studies (Ruttner 1988), $A$. mellifera syriaca consistently clustered with the African bees, regardless of the samples used (24 races of $A$. mellifera vs. exclusively Eastern Mediterranean bees) or the method used to analyze the data (principal component analysis vs. phenogram). An important point is that in his studies, Ruttner first described and grouped many subspecies by geographical locations; using this method the Syrian honeybee is grouped as an Oriental honeybee subspecies. But, after statistical analyses, some of these subspecies clustered in different groups from those described geographically; the Syrian honeybee clustered with the African group. This has created some confusion between 
Table II. Number of samples, haplotype diversity and corrected haplotype diversity for each Syrian, Lebanese, and Iraqi honeybee population.

\begin{tabular}{lllllll}
\hline $\begin{array}{l}\text { Country/ } \\
\text { population }\end{array}$ & $\begin{array}{l}\text { Number of } \\
\text { sample }\end{array}$ & $\begin{array}{l}\text { Haplotype } \\
\text { diversity }\end{array}$ & $\begin{array}{l}\text { Corrected } \\
\text { haplotype } \\
\text { diversity }\end{array}$ & $\begin{array}{l}\text { Excluded } \\
\text { haplotype }\end{array}$ & $\begin{array}{l}\text { Num. of excluded } \\
\text { haplotype }\end{array}$ & $\begin{array}{l}\text { Estimated } \\
\text { introgression \% }\end{array}$ \\
\hline
\end{tabular}

\begin{tabular}{|c|c|c|c|c|c|c|}
\hline \multicolumn{7}{|l|}{ Syria } \\
\hline Damascus & 224 & 0.847 & 0.834 & $\mathrm{C} 1, \mathrm{~A} 2, \mathrm{~A} 3, \mathrm{M} 63$ & $1,7,1,3$ & 5.35 \\
\hline $\begin{array}{l}\text { Rif } \\
\text { Dimashq }\end{array}$ & 187 & 0.878 & 0.875 & C1, M63 & 3,13 & 8.55 \\
\hline As-Suwayda & 192 & 0.839 & 0.820 & $\mathrm{C} 1$ & 13 & 6.77 \\
\hline Hama & 153 & 0.564 & 0.400 & $\mathrm{C} 1$ & 24 & 15.68 \\
\hline Daraa & 96 & 0.818 & 0.818 & - & - & 0 \\
\hline $\begin{array}{l}\text { Al- } \\
\text { Hasakah }\end{array}$ & 160 & 0.178 & 0.178 & - & - & 0 \\
\hline Homs & 73 & 0.776 & 0.763 & $\mathrm{C} 1$ & 1 & 1.36 \\
\hline Idlib & 116 & 0.579 & 0.564 & $\mathrm{C} 1$ & 2 & 1.72 \\
\hline Quneitra & 96 & 0.768 & 0.768 & - & - & 0 \\
\hline Latakia & 137 & 0.766 & 0.745 & $\mathrm{C} 1, \mathrm{C} 3$ & 3,3 & 4.37 \\
\hline Ar-Raqqah & 160 & 0.645 & 0.614 & $\mathrm{C} 3$ & 1 & 0.62 \\
\hline Tartus & 40 & 0.809 & 0.768 & $\mathrm{C} 1, \mathrm{C} 3$ & 3,1 & 10 \\
\hline \multicolumn{7}{|l|}{ Lebanon } \\
\hline Nabatiye & 48 & 0.793 & 0.767 & $\mathrm{C} 1$ & 3 & 6.25 \\
\hline North & 21 & 0.814 & 0.757 & $\mathrm{C} 1$ & 4 & 19.04 \\
\hline Jbeil & 50 & 0.808 & 0.773 & $\mathrm{C} 1$ & 5 & 10 \\
\hline Bekaa & 48 & 0.844 & 0.831 & $\mathrm{C} 1$ & 2 & 4.16 \\
\hline \multicolumn{7}{|l|}{ Iraq } \\
\hline Al Mawsil & 35 & 0.057 & 0.00 & $\mathrm{C} 1$ & 1 & 2.8 \\
\hline
\end{tabular}

Non-local haplotypes (excluded haplotypes) found in each population are cited as well as their numbers and the estimated introgression in each population

$(-)$ Means not found

the subspecies names based on geographical location and the Oriental morphometrical lineage $\mathrm{O}$ that was also described by Ruttner (this confusion is discussed in Kandemir et al. (2006)).

Adding to the confusion, the COI-COII test is not able to discriminate the Oriental lineage $\mathrm{O}$ from the $\mathrm{C}$ lineage. Therefore, the increase of $\mathrm{C}$ lineage in the north and northeast of Syria could be related to an increase in the undetectable $\mathrm{O}$ lineage haplotypes originally located in Turkey and Caucasus.

Our data show that the African lineage A is present in all Syrian and Lebanese honeybee populations; these samples universally contain the Po sequence within their mtDNA COI-COII sequence (Cornuet et al. 1991; Garnery et al. 1993). This specific fragment, which characterizes the A lineage, is not present in the honeybees of Turkey, Caucasus, or Iran (Palmer et al. 2000; Gruev et al. 2005) where the O morphometrical lineage is expected to be (Ruttner 1988). Moreover, the region inhabited by Syrian bees is not part of the geographical area of the morphometrical O lineage described by Ruttner (1988). However, based on samples collected from Lebanon and Syria, Franck et al. (2000) designated new restriction fragment patterns to a putative 


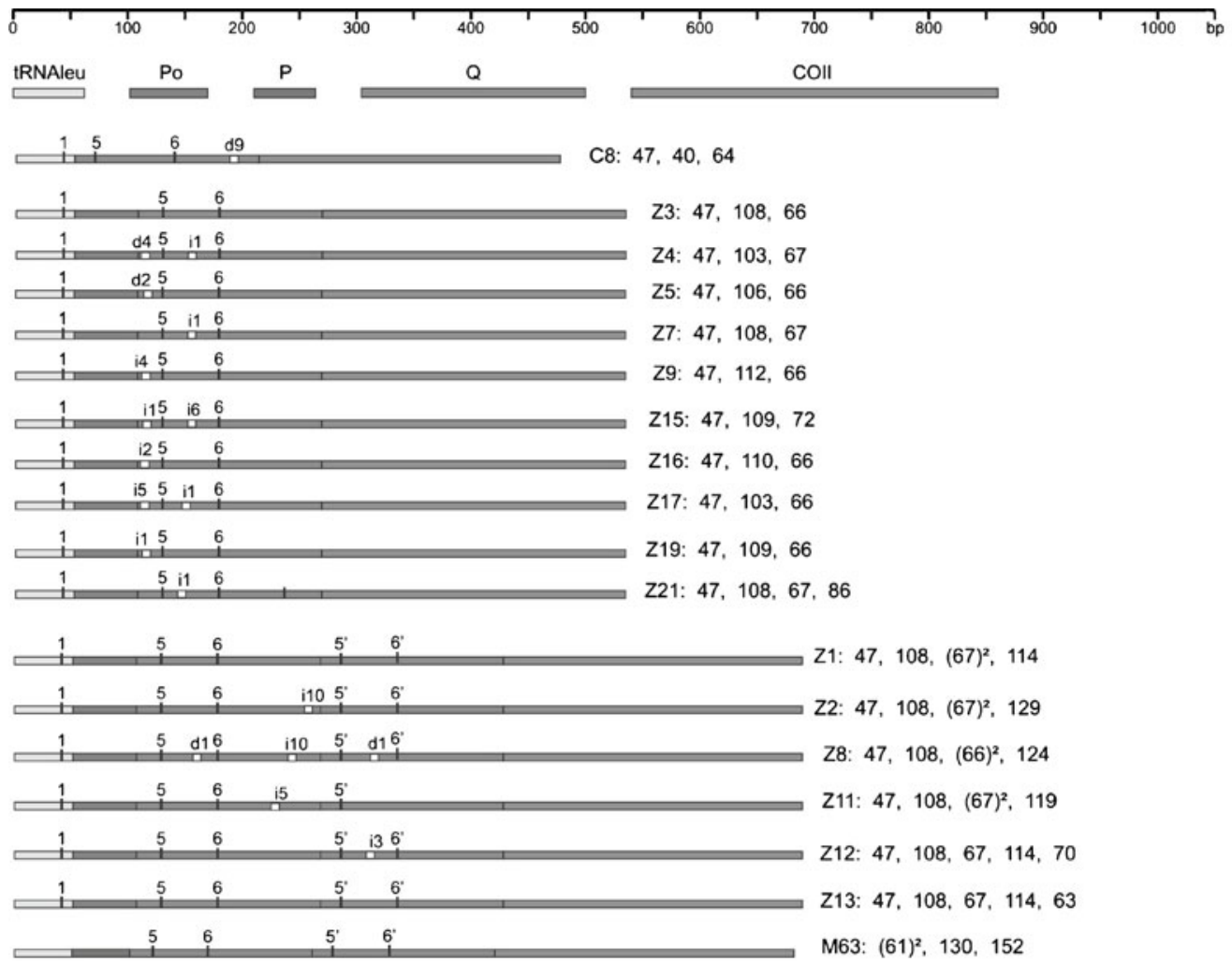

\begin{tabular}{|c|c|c|c|c|}
\hline & $\stackrel{5}{1}$ & 5 & $5^{\prime \prime} \quad 6^{\prime \prime}$ & $72^{\prime}: 47,108,(67)^{3},(129)^{2}$ \\
\hline & 5 i1 6 & $5^{\prime} \quad$ i1 $6^{\prime}$ & $5^{\prime \prime} \quad i 16^{\prime \prime}$ & $Z 1: 47,108,(67)^{3},(114)^{2}$ \\
\hline 1 & 5 i1 6 & 5. i1 $6^{\circ}$ & $5^{\prime \prime} \quad 116^{\prime \prime}$ & $47,108,(67)^{3}, 124,129$ \\
\hline
\end{tabular}

Figure 4. Restriction map corresponding to $21 \mathrm{DraI}$ restricted mtDNA haplotypes containing the $Q$ intergenic COI-COII region length for C8, PQQ for M63 and PoQ, PoQQ, and PoQQQ for the rest. Length of restriction fragments in base pairs are shown with haplotype names on the right. Restriction sites are indicated by vertical line, $d$ and $i$ indicate the number of deletions and insertions in the sequences, respectively.

mitochondrial lineage $\mathrm{O}$. This interpretation is no longer valid. We conclude that Franck et al.'s designation of an $\mathrm{O}$ lineage creates confusion with the $\mathrm{O}$ morphometrical lineage described by Ruttner (1988) and should be avoided.

Our mtDNA results show that the Syrian honeybee has the African structural organization in its COI-COII intergenic region. We consider the populations of $A$. mellifera syriaca, which exhibit these new distinct fragment patterns on the mtDNA in our results, as a subgroup (named Z) of the African lineage A. Therefore, the few Syrian haplotypes previously described as $\mathrm{O}$ digitals by Franck et al. (2001) have been renamed as a $\mathrm{Z}$ subgroup of the $\mathrm{A}$ lineage (Table I). Z haplotypes are sufficiently differentiated to be considered an independent subgroup; they belong to the A branch according to the molecular classification of the three evolutionary lineages $\mathrm{A}, \mathrm{C}$, and $\mathrm{M}$ (presence of the fragment Po) but their sequences differ sufficiently from traditional A haplotypes (Franck et al. 2000). They all contain a new restriction site in position 6 of their COI-COII mtDNA 
Ham-92 Q C8 Ham-74 O C8 Has -60 Q C2

Ham-92 Q C8 Ham-74 Q C8 Has -60 Q C2

Ham-92 Q C8 Ham-74 Q C8 Has -60 O C2

Ham-92 Q C8 Ham-74 O C8 Has -60 O C2

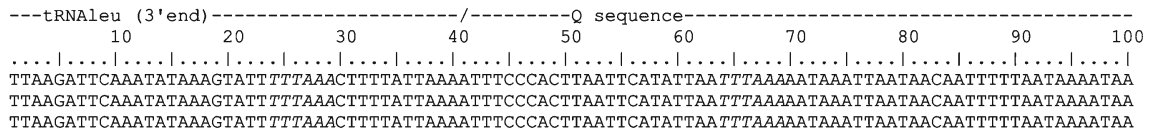

110

120 2

160

170

180

200

ATAATTAATTTTATTTTTATATTGAAT TTTAAATTCAATCTTAAAGATTTAATCTTTTTATTAAAATTAATAAATTAATATAAAA---------TATAA

ATAATTAATTTTATTTTTATATTGAAT TTTAAATTCAATCTTAAGATTTAATCTTTTTATTAAAATTAATAAATTAATATAAAA-------- TATAA

ATAATTAATTTTATTTTTATATTGAAT TTTAAATTCAATCTTAAAGATTTAATCTTTTTATTAAAATTAATAAATTAATATAAAATAAATCACAATATAA

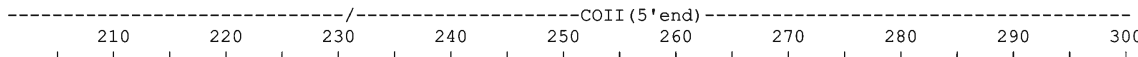
$\ldots \ldots|\ldots| \ldots|\ldots| \ldots|\ldots| \ldots|\ldots| \ldots|\ldots| \ldots|\ldots| \ldots|\ldots| \ldots|\ldots| \ldots|\ldots| \ldots|\ldots| \ldots|\ldots| \ldots|\ldots| \ldots|$. CAGAATATATTTATTAAAATTTAATTTATTAAAATTTCCACATGATTCATATTTATATTTCAAGAATCAAATTCATATTATGCTGATAATTTAATTTCAT CAGATATATTTATTAAAATTTAATTTATTAAAATTTCCACATGATTCATATTTATATTTCAAGAATCAAATTCATATTATGCTGATAATTTAATTTCA CAAAATATATTTATTAAAATTTAATTTATTAAAATTTCCACATGATTCATATTTATATTTCAAGAATCAAATTCATATTATGCTGATAATTTAATTTCAT

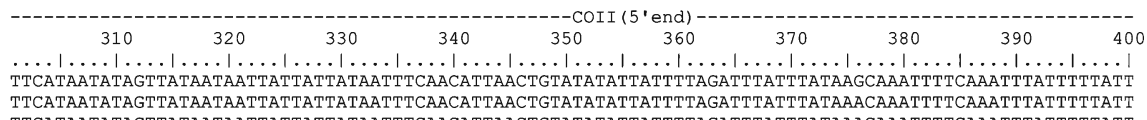
TTCATAATATAGTTATAATAATTATTATTATAATTTCAACATTAACTGTATATATTATTTTAGATTTATTTATAAACAAATTTTCAAATTTATTTTTATT TTCATAATATAGTTATAATAATTATTATTATAATTTCAACATTAACTGTATATATTATTTTAGATTTATTTATAAACAAATTTTCAAATTTATTTTTATT

Figure 5. tRNAleu, Q and COII sequences of the C8 haplotype (Ham-92, Ham-74) and of the C2 haplotype (Has-60). DraI restriction sites are shown in italics while the insertion, the deletion and the substitution are shown in bold.

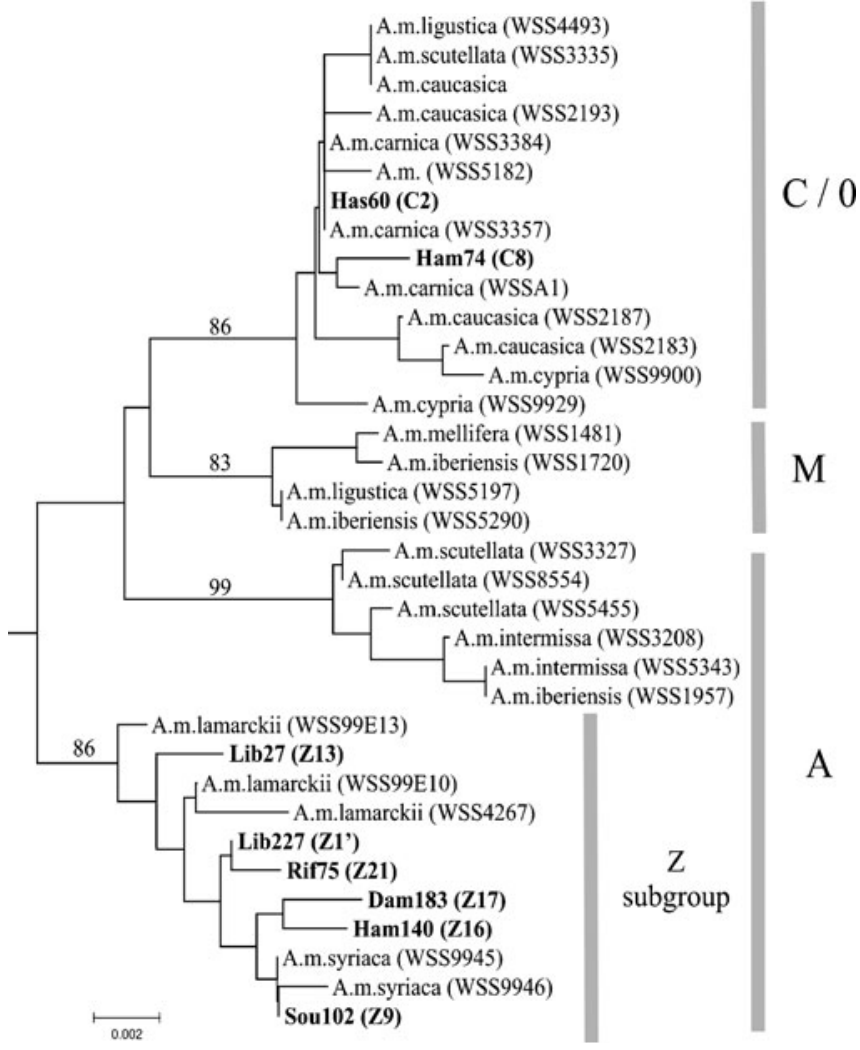

Figure 6. A neighbor-joining tree based on Cyt $b$ sequences performed on nucleotide distances computed by Kimura's (1980) formula through PAUP* program, version Beta 4.0 (Swofford 2002). Apis cerana has been taken as an outgroup, bootstrap values are indicated for the main nodes. $C, O, M$, and $A$ refer to North Mediterranean, Oriental, West Mediterranean, and African lineages, respectively. $Z$ subgroup is a haplotype subgroup of the African lineage $A$. Samples in bold are our samples from Syria and Lebanon, other data are from GenBank (Pinto et al. 2003). 


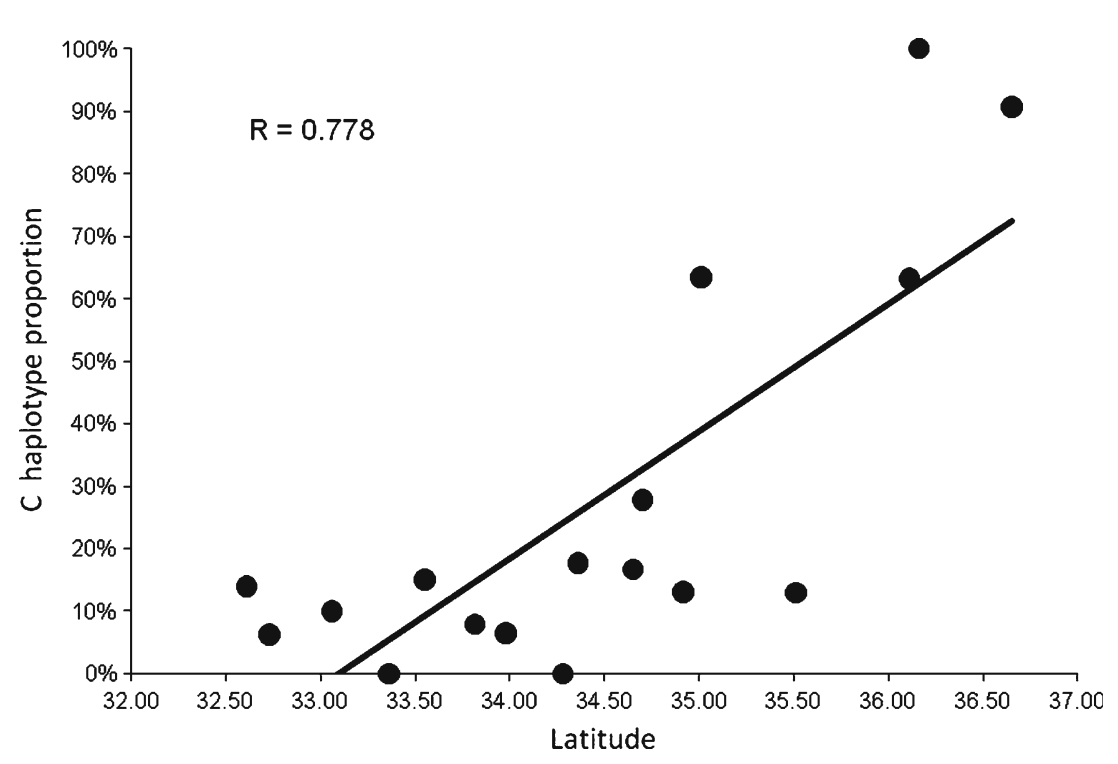

Figure 7. Representation of the north-south gradient of the A and C lineages found in the studied populations. The proportion of $\mathrm{C}$ haplotypes in the population is plotted as a function of the latitude of the locality (in degrees above the equator). The correlation coefficient $R$ is highly significant $(P<0.001)$.

sequence, which gives a new African pattern on polyacrylamide gels. Moreover, the neighborjoining tree performed based on six Cyt $b$ sequences of $\mathrm{Z}$ haplotypes grouped them in an independent subgroup (Figure 6).

The five haplotypes found and previously classified by Franck et al. (2001) on A. mellifera syriaca are $\mathrm{O} 1, \mathrm{O}^{\prime}$ (duplication of $\mathrm{Q}$ sequence), O1" (two duplications of Q sequence), $\mathrm{O} 2$ and $\mathrm{O} 3$. Based on the evidence generated by our study, and particularly our finding that the Syrian honeybee does not belong to the $\mathrm{O}$ morphometrical lineage, we have reclassified these haplotypes as follows (Table I and Figure 3):

- O1 (PoQ) with restriction DraI fragments $(47,108,67)$ corresponds to $\mathrm{Z7}$;

- O1' (PoQQ; 47, 108, (67) ${ }^{2}$, 114) corresponds to $\mathrm{Z} 2$;

- O1" (PoQQQ; 47, 108, $(67)^{3},(129)^{2}$ ) corresponds to $\mathrm{Z2}^{\prime}$;

- O2 (PoQQ; 47, 108, $\left.(67)^{2}, 114\right)$ corresponds to $\mathrm{Z1}$;

- $\quad \mathrm{O} 3$ is the haplotype Z4 (PoQ; 47, 103, 67).
The A lineage is more common in southwest populations $(94 \%$ for the Daraa region in Syria and 94\% in the Nabatiyeh region in Lebanon) than in the north and northeast where the C lineage is dominant (91\% for the Al-Hasakah region). Our analysis indicated a significant correlation between the percentage of $\mathrm{Z}$ haplotypes (African lineage) in the population and the latitude of the sampling locality. In contrast, for the northeast of Syria, going from Tartus to Idlib and Al-Hassaka, the C lineage is clearly dominant; Al-Mawsil in Iraq is $100 \% \mathrm{C}$ lineage (Figure 4). The C2 haplotype was observed at a very high frequency (34/35 samples) in the Iraqi honeybee population from Al-Mawsil.

The C2 haplotype is present at a high frequency in the Al-Hasakah population. This haplotype is found in Turkish populations of A. mellifera anatoliaca in the north as well as in the populations of $A$. mellifera meda present in northeastern Iran (Palmer et al. 2000; Gruev et al. 2005); this haplotype probably spread from northeastern Iran into the North Syrian populations. On the other 
hand, the C2 haplotype is also present in southern Syrian and Lebanese populations far away from the Turkish border. The C8 haplotype found in the Hama honeybee population differs from the $\mathrm{C} 2$ haplotype by a deletion of 10 nucleotides (185-195 bp) in its Q sequence (Figure 5).

Haplotype diversities were estimated for each population and were corrected by eliminating all nonlocal haplotypes present in each of the populations from the calculation (Table II). The lowest haplotype diversity (0.057) and corrected haplotype diversity (0.00) are found in the Al Mawsil population in Iraq (Table II). The highest haplotype diversities are found in Rif Damascus and Damascus, in Syria (Table II), where the most important beekeeping activity is found. The fairly stable corrected haplotype diversities in our study indicate very weak queen importation in those two regions; this same conclusion can be made for the Nabatiyeh and Bekaa populations. In contrast, the Hama population presents the most significant divergence between haplotype and corrected haplotype diversity (0.564 and 0.400 , respectively); this explains why this population also has the highest level of introgression observed in our study (15.68\%; Table II).

The results of this study have revealed evidence of introgression of commercially imported honeybees. The M63 haplotype, which corresponds to the European honeybee (A. mellifera mellifera), has surprisingly been found in two Syrian populations (Damascus and Rif Dimashq, Table II). It is not always easy to detect queen importation; but in this case, the phenomenon was easy to detect because the subspecies belongs to a separate evolutionary lineage ( $\mathrm{M}$ lineage). Two haplotypes (A2 and A3) from the AII group (Franck et al. 2001) have been found in the Damascus population at a low level relative to the number of samples coming from this region. These two haplotypes are not naturally distributed in this area and are more commonly observed in Spain and
Sicily (Franck et al. 2001). These haplotypes were, therefore, imported to the Damascus population (Table II). Imported Buckfast honeybees (Garnery, personal communication), or at least A. mellifera carnica (C3 haplotype), were detected at a low level in Latakia, Ar-Raqqah, and Tartus populations. Imported Italian, C1 haplotype honeybees corresponding to A. mellifera ligustica were detected in almost all populations (Table II).

The mtDNA results of the Syrian and Lebanese populations clearly show that $A$. mellifera syriaca is situated in a geographical contact area between the $\mathrm{A}$ and $\mathrm{O}$ lineages. The number of $\mathrm{C} 2$ haplotypes increases from south to north and are expressed as a proportional increase of the $\mathrm{C}$ lineage (this is because it is not possible to discriminate between the $\mathrm{C}$ and $\mathrm{O}$ lineages using the mtDNA marker). The north-south gradient of $\mathrm{A}$ and $\mathrm{C}$ lineages, presented in Figure 7, underscores the importance of the sampling location; the variation in sampling locations in previous studies might help explain the contradictory views of Syrian honeybee classification. We found no evidence of a conservation threat to the local Syrian honeybee due to massive importation of foreign honeybee subspecies; in fact, we found no evidence of any importation in some populations (Daraa, Quneitra, and AlHasakah; Table II). These areas may be good candidate regions for establishing genetic conservatories for the local honeybee (A. mellifera syriaca) that can help preserve both inter- and intra-population mitochondrial diversity of this honeybee subspecies in each area of the Syrian territory.

\section{ACKNOWLEDGMENTS}

We thank the Syrian beekeeper association and the Ministry of Agriculture in Syria for contributing and facilitating the sampling in most Syrian regions. We are grateful to Jean-Christophe Sandoz for reading this manuscript and making valuable suggestions. 
Structure mitochondriale des populations de l'abeille
'syrienne' (Syrie, Liban et Iraq)

Apis mellifera syriaca / CAPS / haplotype / région intergénique COI-COII/cytochrome oxydase / ADN mitochondrial

\section{Die Struktur von Populationen der Honigbiene in Syrien, dem Libanon und dem Irak anhand mito- chondrialer DNA}

\section{Apis mellifera syriaca / CAPS / Haplotypen / Honigbiene / Zwischengenregion COI-COII / Cyt b / mtDNA}

\section{REFERENCES}

Abrahamovich, A.H., Atela, O., De La Rua, P., Galian, J. (2007) Assessment of the mitochondrial origin of honey bees from Argentina. J. Apic. Res. 46, 191-194

Avise, J.C., Arnold, J., Ball, R.M., Bermingham, E., Lamb, T., Neigel, J.E., Reeb, C.A., Saunders, N. C. (1987) Intraspecific phylogeography: the mitochondrial DNA bridge between population genetics and systematics. Annu. Rev. Ecol. Syst. 18, 489-522

Bodenheimer, F. (1941) Studies on the honeybee and beekeeping in Turkey. Merkez Ziraat Mücadela Enstitüsü, Ankara, Numune matbası, İstanbul

Cornuet, J.M., Garnery, L., Solignac, M. (1991) Putative origin and function of the intergenic region between COI and COII of Apis mellifera L. mitochondrial DNA. Genetics 128, 393-403

El-Niweiri, M.A.A., Moritz, R.F.A. (2008) Mitochontrial discrimination of honeybees (Apis mellifera) of Sudan. Apidologie 39, 566-573

Estoup, A., Solignac, M., Harry, M., Cornuet, J.M. (1993) Characterization of (GT)n and (CT)n microsatellites in two insect species: Apis mellifera and Bombus terrestris. Nucleic Acids Res. 21, 1427-31

Estoup, A., Garnery, L., Solignac, M., Cornuet, J.M. (1995) Microsatellite variation in honey bee (Apis mellifera L.) populations: hierarchical genetic structure and test of the infinite allele and stepwise mutation models. Genetics 140, 679-95

Franck, P., Garnery, L., Solignac, M., Cornuet, J.M. (2000) Molecular confirmation of a fourth lineage in honeybees from the Near East. Apidologie 31, 167-180

Franck, P., Garnery, L., Loiseau, A., Oldroyd, B.P., Hepburn, H.R., Solignac, M., Cornuet, J.M. (2001) Genetic diversity of the honeybee in Africa: microsatellite and mitochondrial data. Heredity 86, 420-30
Garnery, L., Vautrin, D., Cornuet, J.M., Solignac, M. (1991) Phylogenetic relationships in the genus Apis inferred from mitochondrial DNA sequence data. Apidologie 22, 87-92

Garnery, L., Cornuet, J.M., Solignac, M. (1992) Evolutionary history of the honey bee Apis mellifera inferred from mitochondrial DNA analysis. Mol. Ecol. 1, 145-54

Garnery, L., Solignac, M., Celebrano, G., Cornuet, J. M. (1993) A simple test using restricted PCRamplified mitochondrial DNA to study the genetic structure of Apis mellifera L. Experientia 49, 1016-1021

Garnery, L., Mosshine, E.H., Oldroyd, B.P., Cornuet, J.M. (1995) Mitochondrial DNAvariation in Moroccan and Spanish honey bee populations. Mol. Ecol. 4, 465-472

Garnery, L., Franck, P., Baudry, E., Vautrin, D., Cornuet, J.M., Solignac, M. (1998) Genetic biodiversity of the West European honey bee (Apis mellifera and A.m iberica) I: mitochondrial DNA. Evolution 30, 31-47

Gruev E.B., Nikolova M., Donev A. (2005) Morphometric and mtDNA analysis in honeybee populations (Apis mellifera L.) of North and Northwest Iran, Proceedings of the Balkan scientific conference of biology in Plovdiv Bulgaria

Hall, H.G., Smith, D.R. (1991) Distinguishing African and European honeybee matrilines using amplified mitochondrial DNA. Proc. Natl. Acad. Sci. USA 88, 4548-52

Kandemir, I., Pinto, M.A., Meixner, M.D., Sheppard, W. S. (2006) Hinf-I digestion of cytochrome oxidase $I$ region is not a diagnostic test for $A$. m. lamarckii. Genet. Mol. Biol. 29, 747-749

Kimura M. (1980) A simple method for estimating evolutionary rates of base substitutions through comparative studies of nucleotide sequences. J Mol Evol. 16, 111-120.

Moritz, R.F.A., Cornuet, J.M., Kryger, P., Garnery, L., Hepburn, H.R. (1994) Mitochondrial DNA variability in South African honeybees (Apis mellifera L.). Apidologie 25, 169-178

Nei, M., Tajima, F. (1981) DNA polymorphism detectable by restriction endonucleases. Genetics 97, 145-63

Özdil, F., Yildiz, M., Ali, Hall, H., Glenn (2009) Molecular characterization of Turkish honey bee populations (Apis mellifera) inferred from mitochondrial DNA RFLP and sequence results. Apidologie 40, 570-576

Palmer, M.R., Smith, D.R., Kaftanoglu, O. (2000) Turkish honeybees: genetic variation and evidence for a fourth lineage of Apis mellifera mtDNA. J. Hered. 91, 42-6

Pinto, M.A., Johnston, J.S., Rubink, W.L., Coulson, R.N., Patton, J.C., Sheppard, W.S. (2003) Identification of Africanized honey bee (Hymenoptera: Apidae) mitochondrial DNA: validation of a rapid PCR-based assay. Ann. Entomol. Soc. Amer. 96, 670-84

Ruttner, F. (1988) Biogeography and taxonomy of honeybees. Springer, Berlin 
Ruttner, F., Tassencourt, L., Louveaux, J. (1978) Biometrical-statistical analysis of the geographic variability of Apis mellifera. Apidologie 9, 363-381

Sheppard, W.S., Rinderer, T.E., Garnery, L., Shimanuki, H. (1999) Analysis of Africanized honey bee mitochondrial DNA reveals further diversity of origin. Genet. Mol. Biol. 22(n.1), 73-75

Smith, D.R., Palopoli, M.F., Taylor, B.R., Garnery, L., Cornuet, J.M., Solignac, M., Brown, W.M. (1991) Geographical overlap of two mitochondrial genomes in Spanish honeybees (Apis mellifera iberica). J. Hered. 82, 96-100
Swofford, D.L. (2002) PAUP*. Phylogenetic Analysis Using Parsimony (*and other methods). Version Beta 4.0. Sinauer Associates. Sunderland, Massachusetts

Walsh, P.S., Metzger, D.A., Higuchi, R. (1991) Chelex 100 as a medium for simple extraction of DNA for PCR-based typing from forensic material. Biotechniques 10, 506-13

Whitfield, C.W., Behura, S.K., Berlocher, S.H., Clark, A. G., Johnston, J.S., Sheppard, W.S., Smith, D.R., Suarez, A.V., Weaver, D., Tsutsui, N.D. (2006) Thrice out of Africa: ancient and recent expansions of the honey bee, Apis mellifera. Science 314, 642-5 